\title{
SPATIAL-TEMPORAL CHANGES IN PHYTOPLANKTON BIOMASS AND PRIMARY PRODUCTION IN CHWAKA BAY, ZANZIBAR
}

\author{
MNS Kyewalyanga \\ Institute of Marine Sciences, University of Dar-es-Salaam, \\ P. O. Box 668, Zanzibar.
}

\begin{abstract}
Spatial-temporal variations in phytoplankton primary production (PP) and biomass (B) were studied for a period of about one year, from July 1999 to July 2000. In addition, changes in corresponding environmental variables were examined. Sampling took place at two stations in Chwaka Bay, one located in mangrove areas, Station I, and the other in an open area, Station II. Although there were changes both with location and time, there were no clear seasonal trends. Generally, the phytoplankton biomass and primary production (mg C m $m^{-3} h^{-1}$ ) were higher at Station I than at Station II. However, specific production, that is, primary production normalized to phytoplankton biomass, $P^{B}$ (mg C (mg chl-a $)^{-1} h^{-}$ $\left.{ }^{1}\right)$ was higher at station II than at Station I. No relationship could be found between phytoplankton biomass and the rate of primary production. These observations suggest that the presence of the mangrove ecosystem, and the processes therein, influenced the rate of phytoplankton primary production in the Mapopwe Creek, causing the differences between stations.
\end{abstract}

\section{INTRODUCTION}

Phytoplankton are one of the primary producers in aquatic environments. In open ocean waters, autotrophic phytoplankton is the main way through which sun energy is converted to chemical energy. In coastal waters, however, there are other primary producers such as macroalgae, sea-grasses and mangroves. Chwaka Bay is a rich coastal area, with mangroves, coral reefs, and sea-grasses. An interaction of the flora and fauna of such an ecosystem, together with microbial organisms, generate inorganic nutrients required for phytoplankton growth and production. It is therefore expected 
that primary production in an area like Chwaka Bay would be higher than in open ocean waters. Some processes such as nutrient dynamics, and interactions between planktonic and benthic fauna and flora of the Chwaka Bay and Zanzibar waters in general have been studied (Mohammed \& Johnstone 1995, Ndaro et al. 1995, Machiwa \& Hallberg 1995, Wallberg et al. 1999, Wallberg \& Andersson 2000, Kyaruzi pers. comm.). However, only a few studies have been carried out on phytoplankton in Zanzibar waters and have concentrated on biomass (chlorophyll-a measurements) and species composition (e.g. Bryceson 1977, Lugomela 1996) and the identification of toxic and non-toxic microalgae (Lugomela 1996, Silver 1997, Kyewalyanga \& Lugomela 2001).

Only one known determination of the PrI curve for Trichodesmium sp. has been done (Lugomela 1996), and this was based on the oxygen evolution method. Also, using oxygen electrodes in Plexiglas domes, Mohammed et al. (2001) were able to estimate gross community production in Chwaka Bay. In situ determination of phytoplankton primary production, using ${ }^{14} \mathrm{C}$ method, have recently been done for Zanzibar waters (Wallberg et al. 1999, Wallberg \& Anderson 2000). These studies indicated some seasonal differences in the rate of primary production and microbial population structure. The present study aimed at assessing variations in in situ primary production in Chwaka Bay.

The study undertook the following: (i) measurement of phytoplankton primary production, using the carbon-14 method, at two stations in Chwaka Bay, over a period of one year in order to assess its variability both in time and location, (ii) assessment of the variation in the biomass of phytoplankton community and (iii) comparison of the rate of primary production with biomass-specific primary.

The sampling stations were located in the Chwaka Bay, Unguja Island (Fig. 1). Chwaka Bay is a shallow tidal marsh, with an average depth of $2 \mathrm{~m}$ at mean sea level. The surface area ranges from $50 \mathrm{~km}^{2}$ at high water spring to $20 \mathrm{~km}^{2}$ at low water spring (Cederlof et al. 1995). The Bay is located about $34 \mathrm{~km}$ east of Zanzibar town. In the south, it is fringed by a limestone reef, which is extensively covered by a mangrove forest with an approximate area of 3000 ha on the seaward side. The bay opens up to inter-tidal flats covered by sea-grass and algae assemblages (Mohammed \& Johnstone 1995). The first study station (Stn I) was located in Mapopwe Creek, in the 
mangrove area, while the second station (Stn II) was situated in the open bay, over the sea-grass beds.

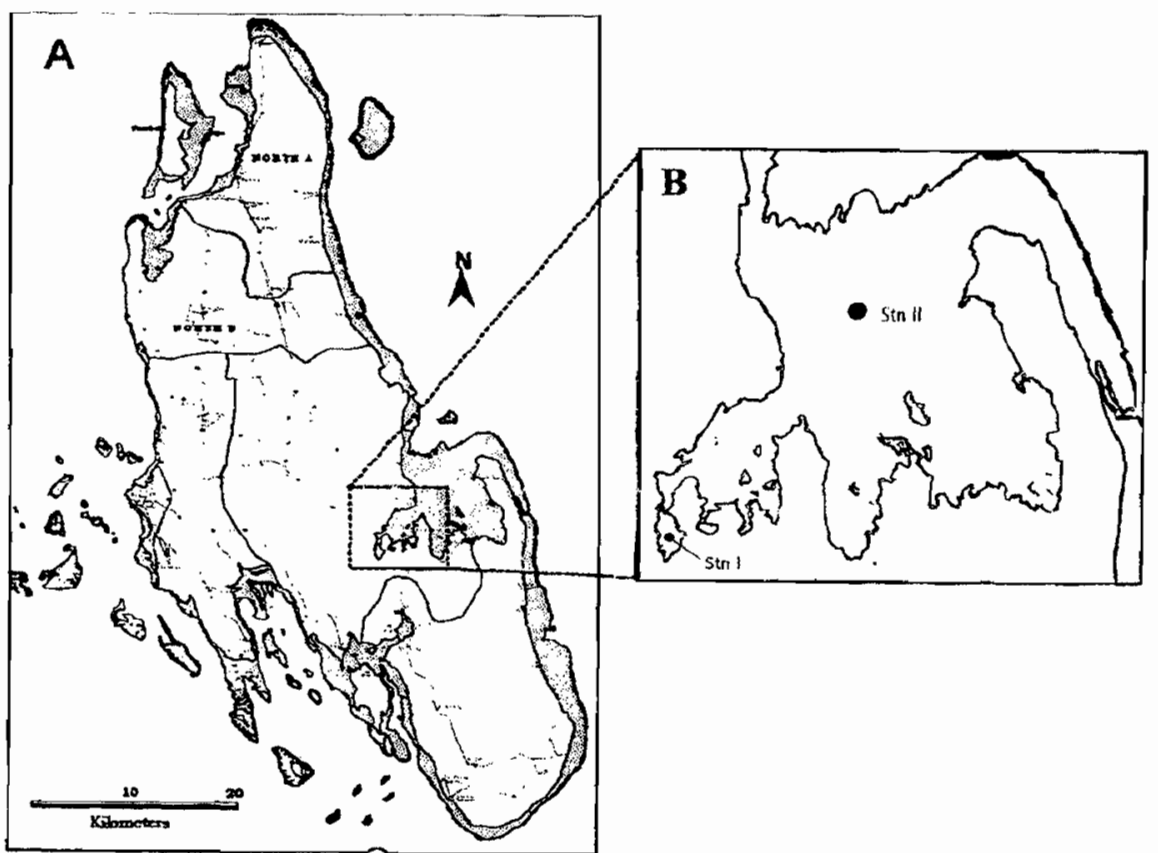

Fig. 1: Map of Zanzibar (A) showing sampling sites at Chwaka Bay (B). Stn I at Mapopwe Creek and Station II at the open bay

The two stations I and II were sampled for a period of about 13 months, from $22^{\text {nd }}$ July 1999 to $21^{\text {st }}$ July 2000 . The sampling frequency was twice a month. However, towards the end of the sampling period (June - July 2000), the frequency of data collection was increased to twice a week. At each station, water samples were collected just beneath the surface, from a depth of approximately $0.2-0.5 \mathrm{~m}$, and used for in situ incubation, determination of chlorophyll-a concentration as well as salinity and temperature. Because the bay was shallow, the collected sample was assumed to be a representative of the entire water column. Chlorophyll-a concentration was determined using a SHIMADZU UV-1201 Spectrophotometer, after extraction into $90 \%$ cold acetone overnight, by the method of Parsons et al. (1984). Rainfall data were obtained from the Department of Meteorology, Zanzibar.

For in situ incubation, $40 \mathrm{ml}$ of water was gently poured into polycarbonate incubation bottles, inoculated with $10 \mu \mathrm{Ci}$ of $\mathrm{NaH}^{14} \mathrm{CO}_{3}$ solution, and 
returned to the depth where they were collected. At each station, one dark and one light polycarbonate bottles were incubated. At the end of the incubation period (4 hours), triplicate sub-samples of 5-ml each (from light and dark bottles) were dispensed into scintillation vials, acidified with 2 drops of $6 \mathrm{M} \mathrm{HCl}$, then bubbled for about 35 minutes to get rid of unincorporated ${ }^{14} \mathrm{C}$. Scintillation fluid $(15 \mathrm{ml}$, Lumagel Safe) was added to the vials, and the samples were counted using a Tri-Carb 2100 TR, Packard (Caniberra Company) scintillation counter.

To account for dark carbon fixation/respiration, average dpm (disintegration per minute) values from the dark bottles were calculated and subtracted from the light-bottle values. The amount of carbon fixed, $P P\left(\mathrm{mg} \mathrm{C} \mathrm{m}^{-3} \mathrm{~h}^{-1}\right)$ was then calculated (Strickland \& Parsons 1972, Parsons et al. 1984). To estimate specific production, $P^{B}\left(\mathrm{mg} \mathrm{C}\left(\mathrm{mg}\right.\right.$ chl-a) $\left.\mathrm{h}^{-1}\right), P P$ values were normalized to the corresponding chlorophyll-a concentration.

\section{RESULTS}

\section{Primary production}

Some temporal variation in $P P, P^{B}$ and chl-a concentration was observed at both Stations I and II. At Stn I, the one located in the mangrove area, the rate of primary production ( $\mathrm{mg} \mathrm{C} \mathrm{m} \mathrm{h}^{-3}$ ) fluctuated throughout the year (Fig. 2). The values showed two major peaks, in August 1999 and July 2000 (dry season), and two small peaks that occurred in November 1999 and March 2000 (rainy season). Throughout the 13 months of data collection, the $P P$ values ranged from $7.54 \pm 0.58$ (in May 2000) to $132 \pm 9.19$ (in July 2000) $\mathrm{mg} \mathrm{C} \mathrm{m} \mathrm{m}^{-3}$. The average $P P$ for the whole period was $53.07 \pm 2.3 \mathrm{mg} \mathrm{C} \mathrm{m}^{-3}$ $\mathrm{h}^{-1}$. The trend and magnitudes in $P P$ observed at the open-waters station (Stn II) were different from those observed at Stn I. The highest value of primary production, $42.7 \pm 6.46 \mathrm{mg} \mathrm{C} \mathrm{m}^{-3} \mathrm{~h}^{-1}$, was observed during November 1999. However, relatively high values were also found during July-August 1999 (Fig. 4). The rate of primary production ranged from 1.66 \pm 0.38 to $42.7 \pm 6.46 \mathrm{mg} \mathrm{C} \mathrm{m}^{-3} \mathrm{~h}^{-1}$ for the entire sampling duration, with an annual mean value of $14.86 \pm 1.86 \mathrm{mg} \mathrm{C} \mathrm{m}^{-3} \mathrm{~h}^{-1}$. This value is less than that calculated for Stn I, by a factor of about 3.6. 


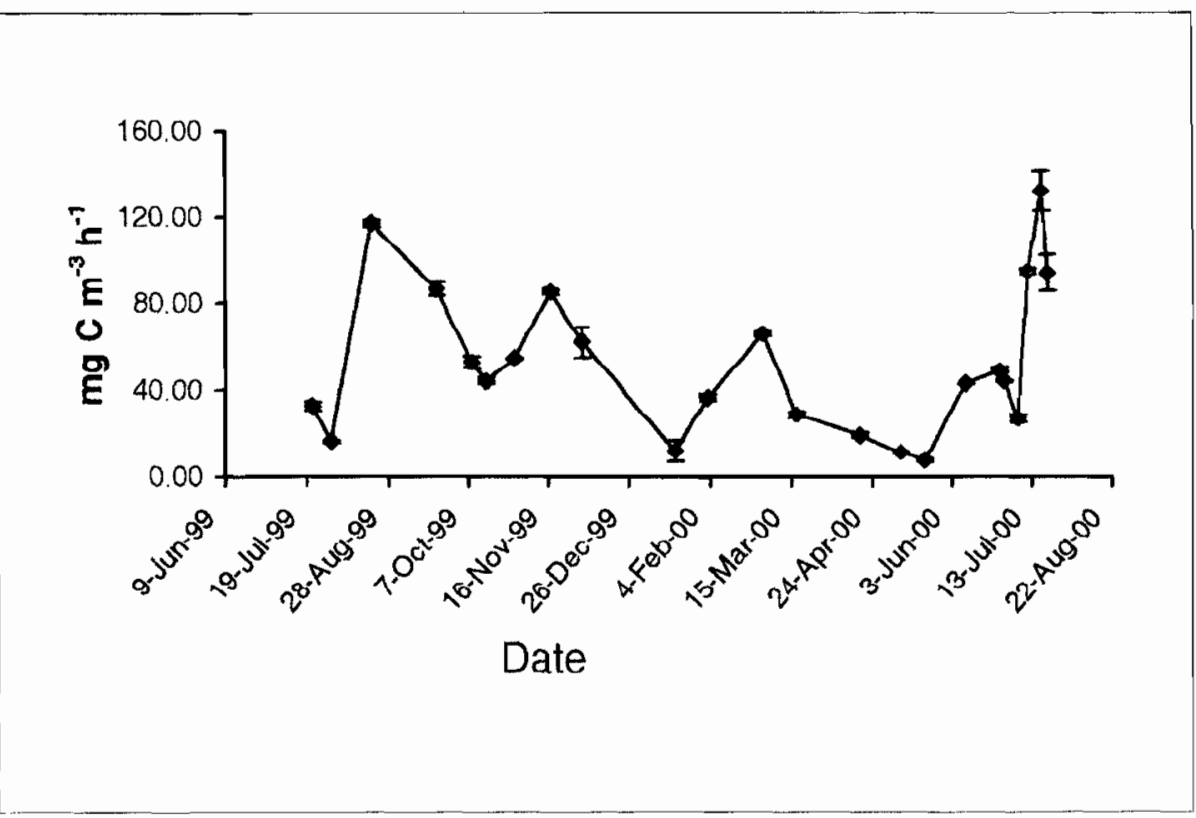

Fig. 2: Temporal variation in the rate of primary production at Station I, Mapopwe Creek, Zanzibar. The error bars are the standard deviations around the mean, $\mathbf{n}=3$

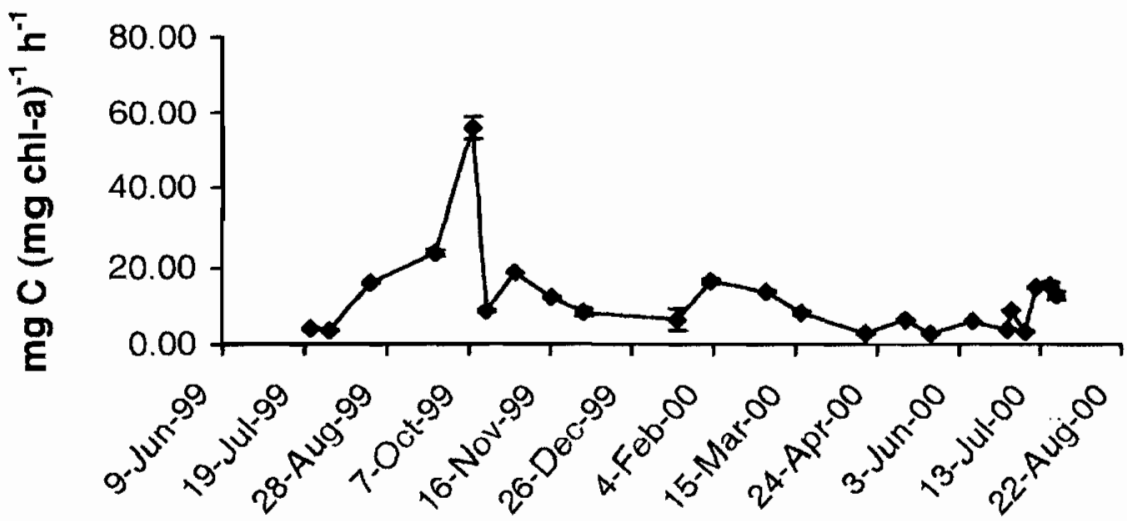

\section{Date}

Fig. 3: Temporal variation in biomass-specific primary production at Station I, Mapopwe Creek, Zanzibar. The error bars are the standard deviations around the mean, $\mathrm{n}=3$ 


\section{Specific primary production}

The biomass-specific primary production values, $P^{B}\left[\mathrm{mg} \mathrm{C}(\mathrm{mg} \mathrm{chl}-\mathrm{a})^{-1} \mathrm{~h}^{-1}\right]$, i.e., $P P$ normalized to chlorophyll-a concentration, were calculated for both stations. This was done to examine the relationship between primary production and phytoplankton biomass. The result shows that the trend in the rate of primary production is not necessarily the same as that in the biomass-specific production (Figs. 3 and 5). At Station I, $P^{B}$ values increased with time from July 1999, reaching a peak in October, (Fig. 3). The $P^{B}$ values at Stn I ranged from $2.97 \pm 0.23$ to $56.02 \pm 2.93$ with an average of $11.98 \pm 0.58 \mathrm{mg} \mathrm{C}(\mathrm{mg} \mathrm{chl}-\mathrm{a})^{-1} \mathrm{~h}^{-1}$, for the whole year. Coincidentally, specific production at Stn II showed the highest peak exactly at the same time, i.e., in October 1999. However, as a contrary, other four small peaks were observed during the months of July1999, as well as in January, March and June 2000 (Fig. 5). For this station, the values ranged between $0.24 \pm 0.06$ and $47.81 \pm 10.07 \mathrm{mg} \mathrm{C} \mathrm{(mg} \mathrm{chl-a)})^{-1} \mathrm{~h}^{-1}$. The average value for the entire 13 months was $12.17 \pm 1.73 \mathrm{mg} \mathrm{C}(\mathrm{mg} \mathrm{chl}-\mathrm{a})^{-1} \mathrm{~h}^{-1}$. Despite the differences in the trend in $P^{B}$, the annual averages did not differ significantly between the two stations.

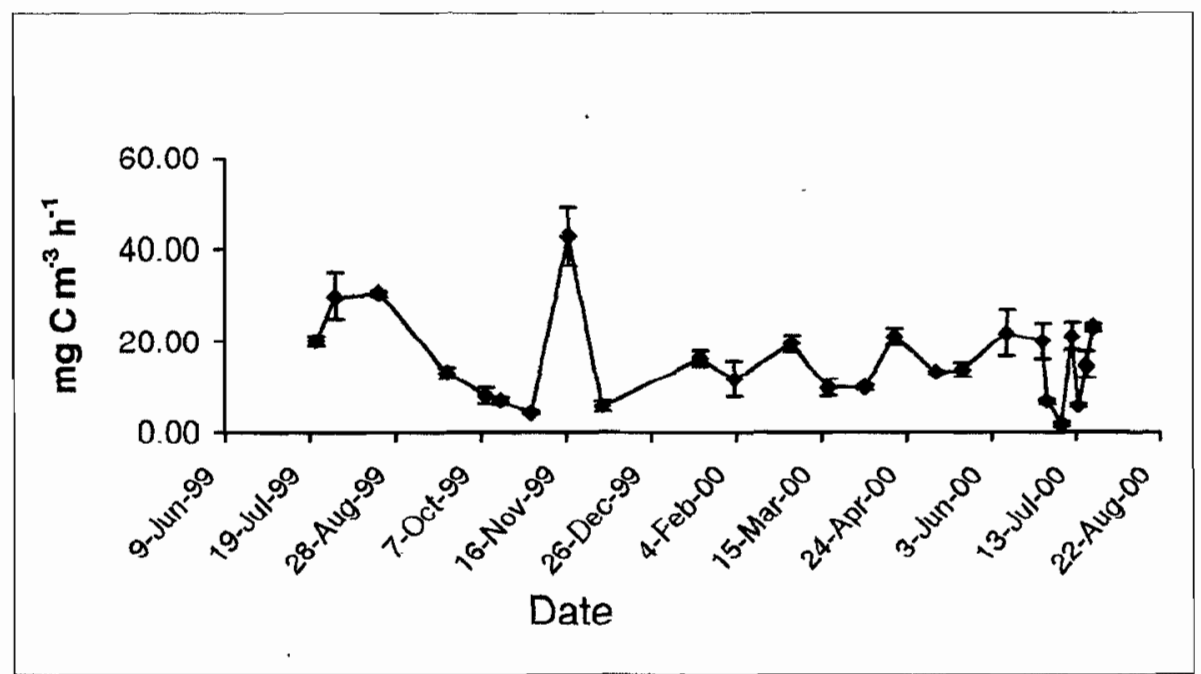

Fig. 4: Temporal variation in the rate of primary production at the open bay Station II, Zanzibar. The error bars are the standard deviations around the mean, $\mathbf{n}=3$ 


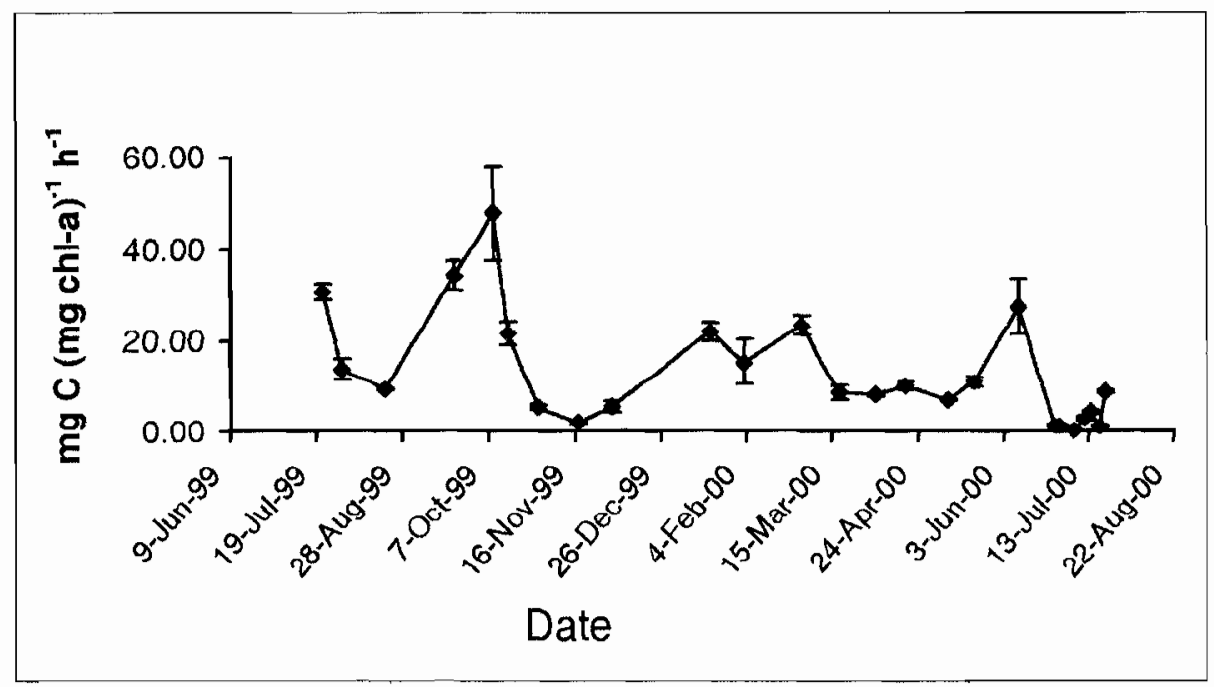

Fig. 5: Temporal variation biomass-specific primary production at the open bay Station II, Zanzibar. The error bars are the standard deviations around the mean, $n=3$

\section{Chlorophyll-a concentration}

The concentration of chlorophyll at Stn I, varied with time of the year. Relatively higher values were observed between July and August in 1999 and from June to August in 2000 (Fig. 6a). The range in the concentration of chlorophyll-a was between 0.96 and 12.14, with an annual average of $5.54 \pm$ $2.8 \mathrm{mg} \mathrm{m}^{-3}$. At Stn II, chlorophyll-a concentration was low for most of the time, with concentrations below $2.5 \mathrm{mg} \mathrm{m}^{-3}$. However, some occasional strong peaks were also seen (Fig. 6b). The highest value in chlorophyll-a concentration corresponded with the highest value in the rate of primary production, at Stn II, and this happened during the short rains in November 2000. A phytoplankton bloom was also observed during this time. For the entire sampling period, the chlorophyll-a concentration ranged from 0.11 to 19.74 , with a mean value of $3.72 \pm 5.2 \mathrm{mg} \mathrm{m}^{-3}$.

To assess the relationship between primary production and phytoplankton biomass, the $P P$ values were plotted as a function of chlorophyll-a concentration (Figs. 7a \& b). Both at Stations I and II, there seemed to be no correlation between $P P$ and $B$. At Stn I, the data are scattered throughout the graph, while for Stn II, most data points are confined within a narrow range of biomass (between 0 and $2 \mathrm{mg} \mathrm{m}^{-3}$ ), regardless of the magnitude in the rate of primary production, which ranged between 0 and $30 \mathrm{mg} \mathrm{C} \mathrm{m}^{-3} \mathrm{~h}^{-1}$. It is 
obvious from figures $7 \mathrm{a}$ and $\mathrm{b}$ that one can observe low production at high chlorophyll concentrations and vice versa.

\section{Variation in environmental variables}

Temperature and salinity also showed changes with time of the year, however, the trend for these parameters seemed to be somehow similar at the two stations (Figs. 8a \& b). With exception of one datum point, in February 2000 at Stn I, high values in water temperatures were observed between late October 1999 and early April 2000 (Fig. 8a). From late April 2000 to the end of the sampling time, water temperature decreased steadily at both Stns I \& II. At Stn I, temperature ranged from $24.0 \beta C$ to $30.5 \beta C$, with an average of $27.5 \pm 1.94{ }^{\circ} \mathrm{C}$. Station II showed similar annual range and mean. The mean for Stn II was $27.5 \pm 1.81{ }^{\circ} \mathrm{C}$, and ranged from 25 to $31^{\circ} \mathrm{C}$.

The fluctuations in salinity with time seem to be somehow the opposite to that of temperature, especially from February to July 2000 (compare Fig. 8a with Fig. 8b). During this period, salinity at Stn I was lower than at Stn II (Fig. 8b). As for the water temperature, annual means in salinity did not seem to vary significantly between the two stations; $33.1 \pm 4.33 \%$ for Stn I and $35.1 \pm 2.47 \%$ for Stn II. Rainfall data, obtained as daily values, were converted to monthly totals (Fig. 9). Those months showing monthly totals less than $100 \mathrm{~cm}$ were considered as dry season, and those having more than $100 \mathrm{~cm}$ as rainy season. In this respect, the rainy seasons during the sampling time was between November and December 1999 (short rains) and from March to June 2000 (long rains; see Fig. 9). 

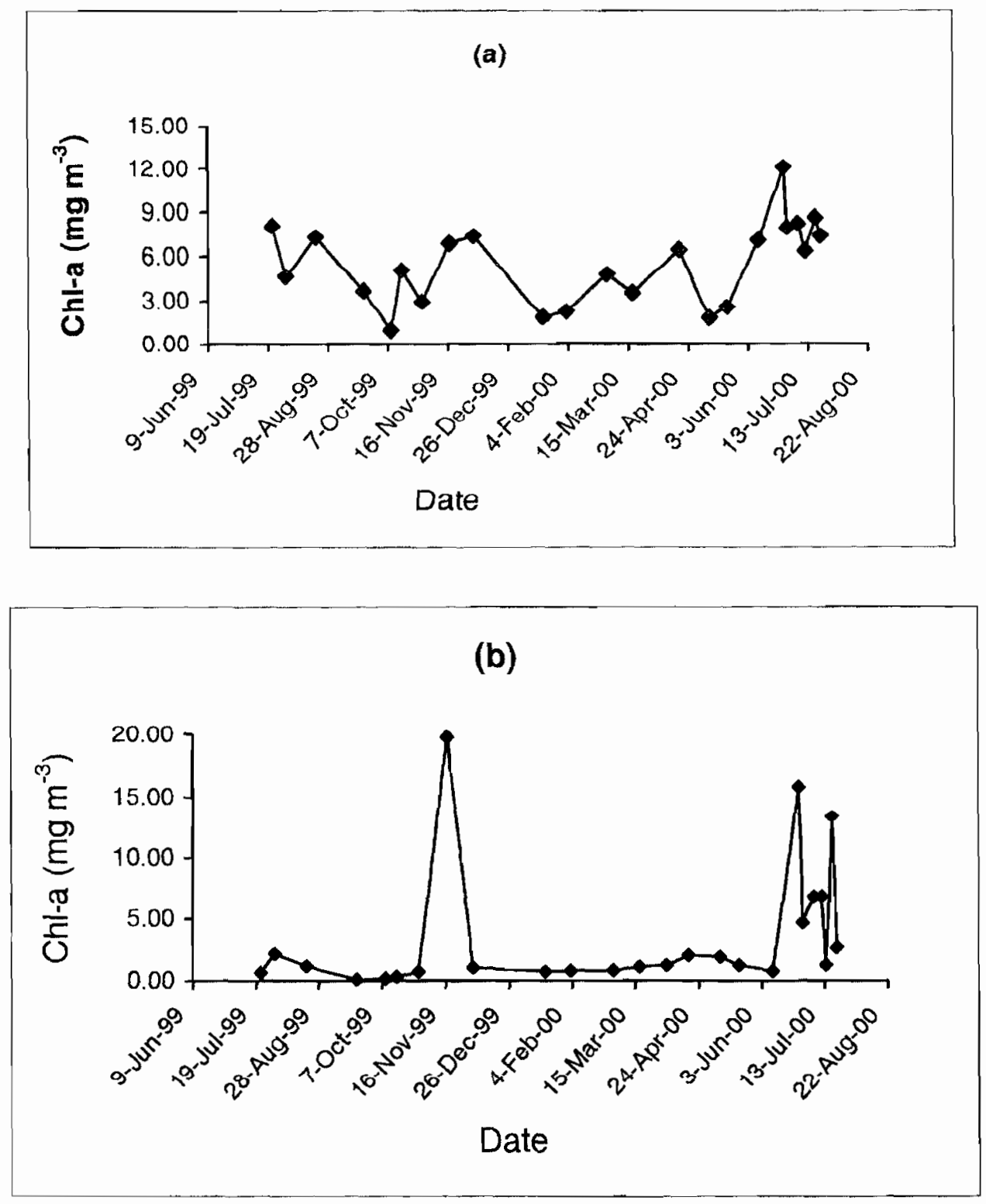

Fig. 6. Temporal variation in chlorophyll-a concentration ( $\left.\mathrm{mg} \mathrm{m}^{-3}\right)$ for data collected from July 1999 to July 2000: (a) Station I, Mapopwe Creek, Zanzibar and (b) Station II, the open bay, Zanzibar 

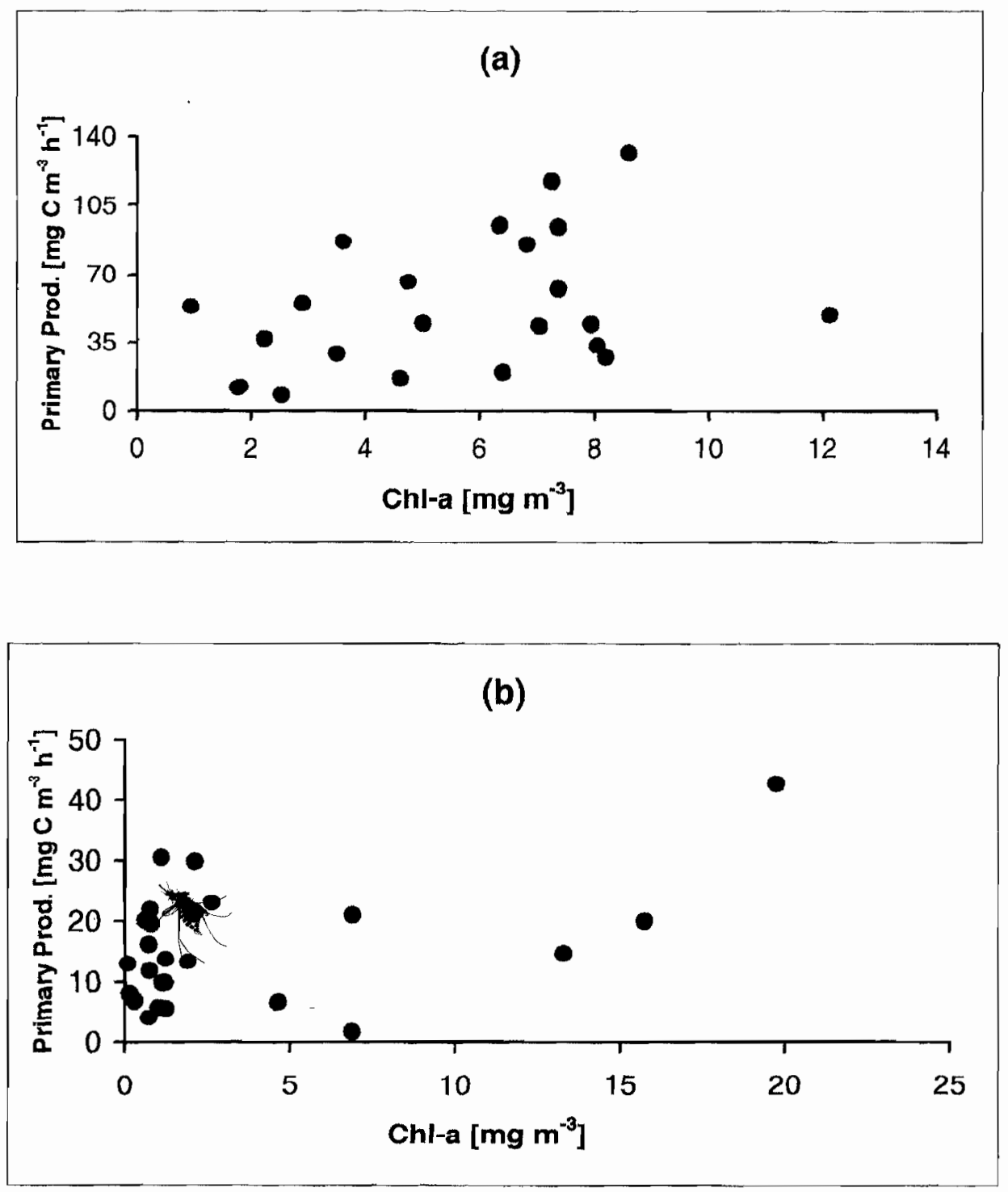

Fig. 7. Relationship between the rate of primary production and phytoplankton biomass, expressed as chlorophyll-a (chl-a) concentration for (a) Station I, Mapopwe Creek, Zanzibar and (b) Station II, the open bay, Zanzibar. The data covers 13 months of sampling, from July 1999 to July 2000 

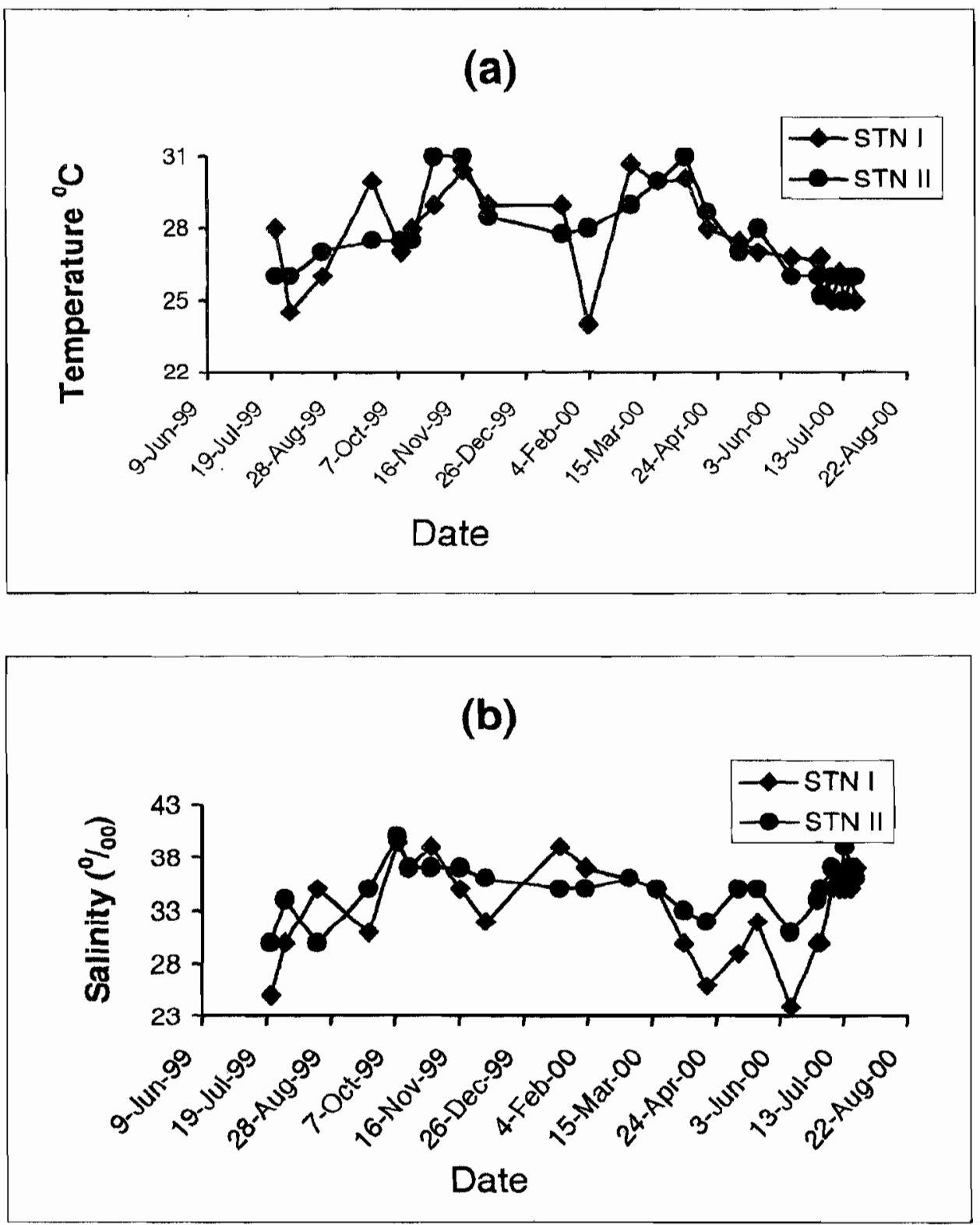

Fig. 8. Temporal variation in (a) temperature and (b) salinity for a period between July 1999 and July 2000. Diamond symbols show data for Stn I, Mapopwe Creek, Zanzibar, while closed circles indicate data for Stn II, the open bay, Zanzibar 


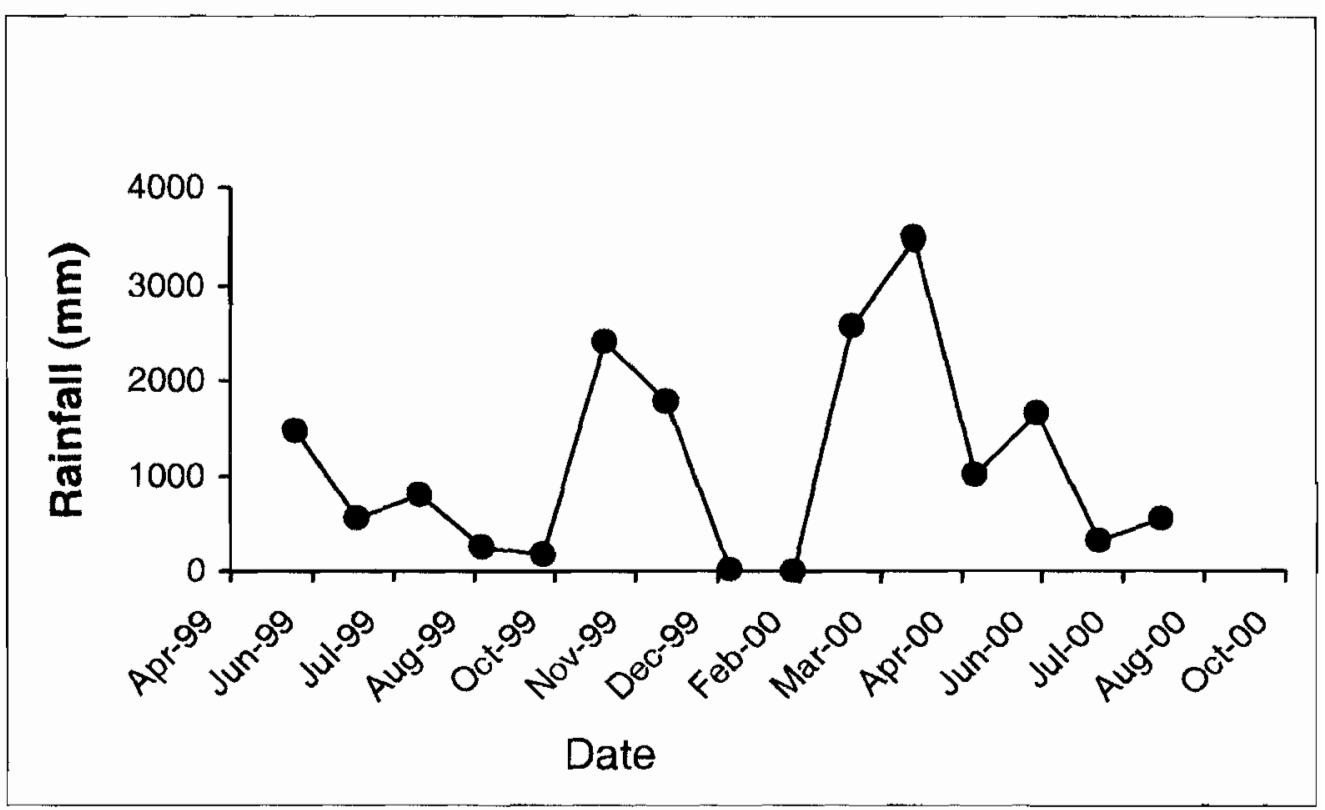

Fig. 9. Total monthly rainfall (mm) for Zanzibar, from June 1999 to August 2000

\section{DISCUSSION}

Since no work had been done on ${ }^{14} \mathrm{C}$-based primary production in Chwaka Bay, the present study looked at spatial and temporal variations in the rate of in situ primary production and other variables. Overall, the rate of primary production, the biomass-specific production, chlorophyll-a concentration, water temperature and salinity, exhibited both temporal and spatial variations. Earlier studies carried out in Chwaka Bay (Mohammed \& Johnstone 1995) reported a reverse in the seasonal variations of nitrate $v s$. ammonia. Such differences could trigger variations in the biological processes that depend on them. In addition to temporal variations, spatial changes in the bay were also observed. Although the two stations were not located very far apart (Fig. 1), the fact that one station was in the mangrove areas and the other in the open bay could have influenced the rate of primary production and other parameters. In general, the rate of primary production for the Mapopwe-Creek Station, the area surrounded by a mangrove forest, was much higher than that at the open ocean station. This variation could have been caused by differences in the concentration of inorganic nutrients. No nutrient measurements were carried out during the present study, however, the work done previously in Chwaka Bay (Mohammed \& Johnstone 1995) indicated strong spatial variability in the nutrients in 
Mapopwe Creek, with concentrations decreasing as the water traverses the waterway towards the open bay. Furthermore, Mohammed and Johnstone (1995) concluded that there was no net transport of nutrients from Mapopwe Creek to the open bay. In another study, Johnstone et al. (unpublished report) observed that the mangroves of Mapopwe Creek exported particulate organic matter, and it received dissolved inorganic nitrogen from adjacent environments. This implies that there are more nutrients in the Mapopwe Creek (Stn I) than in the open bay (Stn II). In addition, the benthic community of the Mapopwe Creek is dominated by nitrogen-fixing cyanobacteria that are missing at the open-bay station (Lugomela \& Kyaruzi, person comm.). Mohammed and Johnstone (2001) reported that the sediments in Mapopwe Creek were found to be a source of ammonia, while in another study it was found that there is export of particulate organic matter from the mangroves (Mapopwe Creek, Stn I) to the sea-grass beds (Mohammed et al. 2001).

\section{Seasonal variation in primary production}

For Stn I, highest values in primary production were observed during the dry season (compare Figs. 2 with 9a). On the contrary, the highest value for Stn II was observed during the short rains, while some high values also occurred during the dry season for the year 1999 (Fig. 4). However, biomass-specific primary production did not differ very much between the two stations. Nevertheless, generally speaking, the values at Stn II were higher than those observed at Stn I, which is the opposite situation from that of the rate of primary production. At the Mapopwe Creek station, there was no conspicuous relationship (pattern) between primary production $\left(\mathrm{mg} \mathrm{C} \mathrm{m}^{-3} \mathrm{~h}^{-1}\right)$ and specific production $\left(\mathrm{mg} \mathrm{C}(\mathrm{mg} \mathrm{chl-a})^{-1} \mathrm{~h}^{-1}\right)$ (Figs. $2 \& 3$ ). But also the pattern in the rate of primary production at Stn II appears to be the opposite of the pattern on specific production (compare Fig. 4 with 5). Low values of specific production occurred during the rainy seasons, at both stations I \& II (Figs. 3 \& 5). The peaks in specific production, that occurred in October 1999, at both stations, corresponded to low amount of rainfall, just before the beginning of short rains (Fig. 9).

These observation could imply that at station I, there were several factors, other than biomass, that influenced the rate of primary production (e.g. nutrients availability) where as at station II the biomass could be playing a bigger role. This is because, station II was probably nutrient limited since there is known to be a decrease in nutrients as one moves towards the open 
bay, from mangrove areas (Mohammed \& Johnstone 1995). For example, Mohammed et al. (2001) found that a site farther from the mangrove forest in Chwaka Bay exhibited higher gross community production (GPP) than the one located in the mangrove forest. The authors attributed the high production to the contribution of high epiphytic communities found at such sites and that GPP may not be directly coupled to mangrove export. Comparing only $P P$, station I appeared to be more productive than station II. However, if $P^{B}$ is also taken into consideration, the differences between the two stations did not appear to be significant. If we assess the difference in $P P$ and $P^{B}$ within stations, we find a difference in those values for station I, while the values for $P P$ and $P^{B}$ are not so different at station II. In spite of this, there was no clear correlation between the rate of primary production and the biomass at both stations I and II, for the entire sampling period of 13 months (see Figs. 7 a \& b), although the data points are less scattered for station II than for station I. These results suggest that one cannot just determine phytoplankton biomass and be able to infer or predict the rate of primary production. In other words, higher biomass does not necessarily indicate high rates of primary production and vice versa.

The exception could be seen at station II during October-November 1999. During this time, there was a peak in both primary and biomass-specific primary production; in chlorophyll concentration as well as in temperature and salinity. September-October was usually a period of strong sunshine and winds. Given enough nutrients in the water, and because the bay is shallow, such conditions were conducive for high rates of production (photosynthesis) and increase in phytoplankton biomass (growth and reproduction). Another thing to note is that primary production peaked during November 1999, while specific primary production peaked in September - Octoberand it was low in November due to normalization for phytoplankton biomass (chlorophyll-a), which was highest during that month.

The present study has therefore revealed that, for Chwaka Bay, phytoplankton biomass and primary production vary both with time and space. Unlike the situation reported for previous studies carried out off Zanzibar waters (Wallberg et al. 1999, Wallberg \& Anderson 2000), the rate of primary production observed in Chwaka Bay could be attributed to seasons of the year. While Wallberg et al. (1999) found higher primary production during the rainy season, probably due to nutrient input via 
surface run-off, in the current study, high production was found mostly during the dry season.

The two stations sampled showed big differences in the rate of primary production, specific production and phytoplankton biomass. It can be concluded that, phytoplankton biomass (as chlorophyll-a concentration) cannot be taken as a proxy for the rate of primary production. It is recommended that in order to identify factors that regulate the rate of primary production in Chwaka Bay, detailed studies including nutrient measurements should be undertaken. Further, the number of stations to be sampled need to be increased to get a better understanding of spatial variation, that will include statistical treatment of data.

\section{ACKNOWLEDGEMENT}

The author would like to thank the assistance provided by Charles Lugomela, Thomas Buluda and Jasson Kyaruzi during data collection and some laboratory analysis. The assistance of the boatman, Iddi Khamis, is also appreciated. The author would also like to thank the two anonymous reviewers for their constructive comments on the manuscript. The grant for carrying out this research was provided by Sida-SAREC through the Core Support Program.

\section{REFERENCES}

Bryceson I 1977 An ecological study of the phytoplankton of the coastal waters of Dar es Salaam. Ph.D. Thesis, University of Dar es Salaam, Tanzania

Cederlof U, Rydberg L, Mgendi M and Mwaipopo O 1995 Tidal exchange in a warm tropical lagoon, Chwaka Bay, Zanzibar. Ambio 24: 458-464

Kyewalyanga M and Lugomela C 2001 Existence of potentially harmful microalgae in coastal waters around Zanzibar: a need for a monitoring program. In: Richmond MD and Francis $\mathrm{J}$ (eds). Marine science development in Tanzania and eastern Africa. Proceedings of the $20^{\text {th }}$ Anniversary Conference on Advances in Marine Sciences in Tanzania. 28 June - 1 July 1999, Zanzibar, IMS/WIOMSA 569 pp 
Lugomela C 1996 Studies on phytoplankton in the nearshore waters of Zanzibar. MSc. Thesis, University of Dar es Salaam, Tanzania

Machiwa JF and Hallberg RO 1995 Flora and crabs in a mangrove forest partly distorted by human activities, Zanzibar. Ambio 24: 492-496

Mohammed SM and Johnstone RW 1995 Spatial and temporal variations in water column nutrient concentrations in a tidally dominated mangrove creek: Chwaka Bay, Zanzibar. Ambio 24: 482-486

Mohammed SM and Johnstone RW 2001 Pore water nutrient profiles and nutrient sediment-water exchange in a tropical mangrove waterway, Mapopwe Creek, Chwaka Bay, Zanzibar. African Journal of Ecology (in press)

Mohammed SM, Johnstone RW, Widen B and Jordelius E 2001 The role of mangroves in the nutrient cycling and productivity of adjacent seagrass communities; Chwaka Bay, Zanzibar. In: Richmond MD and Francis $\mathbf{J}$ (eds). Marine science development in Tanzania and eastern Africa. Proceedings of the $20^{\text {th }}$ Anniversary Conference on Advances in Marine Sciences in Tanzania. 28 June - 1 July 1999, Zanzibar, IMS/WIOMSA $569 \mathrm{pp}$

Ndaro SGM, Sjoling S and Olafsspm E 1995 Small-scale variation in major meiofaunal taxa and sediment chemistry in tropical sediments. Ambio 24: 475-481

Parsons TR, Maita Y and Lalli CM 1984 A manual of chemical and Biological methods for seawater analysis. Pergamon Press, Oxford. $173 \mathrm{pp}$

Strickland JDH and Parsons TJ 1972 A practical handbook of seawater analysis. Bull. Fish. Res. (Bd. Canada) 167: $311 \mathrm{pp}$

Wallberg P and Andersson A 2000 Transfer of carbon and a polychlorinated biphenyl through the microbial food web in a tropical coastal ecosystem. Environmental Toxicology and Chemistry 19: 827-835

Wallberg P, Jonsson PR and Johnstone R 1999 Abundance, biomass and growth rates of pelagic microorganisms in a tropical coastal ecosystem. Aquatic Microbio Ecology 18: 175-185 